\title{
The Effect of the Credit Deciding Authority Competency and the Effectiveness of Applying the Four Eyes Principle to Minimize Non Performing Loans on Small Medium Enterprise Segment in Pt. Bank Mandiri (Persero) Tbk Region I Sumatera I
}

\author{
Edi Faisal Harahap ${ }^{1}$, Harmein Nasution², Yeni Absah ${ }^{2}$ \\ ${ }^{1,2}$ Master of Management on Postgraduate School of University of Sumatera Utara
}

Corresponding Author: Edi Faisal Harahap

\begin{abstract}
This study aims to determine and analyze the influence of the competence of credit decision authority and the effectiveness of the application of the Four Eyes Principle to minimize nonperforming loans in the Small Medium Enterprise (SME) segment at PT. Bank Mandiri (Persero) Tbk Region 1 Sumatera 1. The results of this study are expected to be useful input for controlling non-performing loans in the SME segment through developing the competency of authority holders and implementing the Four Eyes Principle as an effort to manage risks that may arise in lending.

This research was conducted by distributing questionnaires to all authority holders in Region I Sumatera I consisting of SME and Retail Risk Management Units spread across the Sumatera I Region and 7 Area offices totaling 31 authority holders. In taking the sample of this study using a non-probability sampling method. The results showed that of the 5 factors that make up competence, the sub-variables of nature and character are the components that significantly play a role in the competence of the authority holder in making credit decisions. Whereas the application of the Four Eyes Principle method is the most appropriate risk management strategy in making credit decisions for the SME segment, however, the most suitable Four Eyes Principle is the Symmetry model. In this study, it was also revealed that weak monitoring is also the most important thing that should be the
\end{abstract}

attention of Bank Mandiri to minimize nonperforming loans.

Keywords: Competence of authority holders, Four Eyes Principle, non-performing loans.

\section{BACKGROUND}

The problem of non-performing loans in the Small Medium Enterprise (SME) segment is not only suspected to be caused by the debtor's condition but also due to internal factors such as the quality of credit decisions made by credit authority holders at Bank Mandiri that are not prudent and the credit decision-making mechanism imposed by the bank. From the debtor's point of view, credit problems can be caused by, among others, the poor character of the debtor or due to the debtor's lack of business experience or due to the debtor's business potential which is actually less prospective. However, errors originating from the debtor's internal factors should be detected early by the committee of authority when the credit application is proposed by a marketing staff, so that the bank authority holder rejects the debtor's request.

On the other hand, in order to prevent or reduce non-performing loans in making credit decisions, Bank Mandiri has implemented a decision-making mechanism using the Four Eyes Principle (FEP) model, which is a principle in exercising the 
Edi Faisal Harahap et.al. The effect of the credit deciding authority competency and the effectiveness of applying the four eyes principle to minimize non performing loans on small medium enterprise segment in Pt. Bank Mandiri (Persero) Tbk Region I Sumatera I.

authority to decide credit that must be carried out by 2 authorities. However, the Four Eyes Principle model has not been able to ensure that any credit terminated by the authority holder will be completed properly in accordance with the credit agreement that has been agreed between the debtor and the bank.

However, based on Bank wide data in Region 1 Sumatera 1, the segment of Small and Medium Enterprises (SMEs) and Micro (secured loans / productive micro) shows a deteriorating trend in nonperforming loans since 2015 IDR 437.57 billion or $4.49 \%$ of the total SMEs distributed of IDR 9,745 Trilion, in 2016 non-performing loans reached IDR 565 billion or $6.66 \%$ of the total loan disbursement of IDR 8,492 Trilion. In 2017, it decreased to IDR 336.7 Billion or $4.40 \%$ of the total credit of IDR 7,642 Trilion. If we examine more than the data, it can be seen that the management is also implementing an aggressive write-off strategy, IDR 274 Billion (2015), IDR 596 Billion (2016) and IDR 677.13 Billion (2017).

Based on the data above, the phenomenon of non-performing loans in the Small Medium Enterprise (SME) segment is interesting to study, especially to find out the correlation between the Four Eyes Principle concept being applied as one of the credit decision-making methodologies and how the role of authority holders is able to minimize problem loans early. The direct variable that is thought to have an impact on non-performing loans is the competence of the authority holder. Competence is the knowledge, skills and abilities as well as character that are directly related to the performance and quality of credit decisions. According to Karim (2004) the risk of financing can arise because of the wrong financing analysis carried out by employees of financial institutions. To reduce this risk, banks need trained and experienced staff. Another direct variable that is thought to have an impact on non-performing loans is the application of the Four Eyes Principle model in each credit extension. In this second variable, we will see the effectiveness of the Four Eyes Principle model applied by Bank Mandiri as a strategy in making credit decisions.

Based on previous research conducted by Supriadi (2008) Risk Management Analysis on Commercial Financing of Sharia Business Unit PT. Bank Tabungan Negara (Persero) Tbk. (A "Four Eyes Principle" Method Approach) shows the successful implementation of the Four Eyes Principle (FEP) in the Sharia Business unit at BTN in order to minimize the risk of disbursement of funds. Risk is measured through the ratio of non-performing financing (NPF). Factors suspected of having an effect on NPF are profit, FDR, OEOI and bank size. The analytical method used is panel data regression with the fixed effect model approach and difference test $(\mathrm{t}$ test). The results show that FEP has succeeded in reducing the NPF ratio, this is evident from statistical processing that FEP has a negative effect on NPF and is also strengthened by the $t$ test that there is a significant difference in the NPF value before and after the application of FEP. Other variables that have a positive effect on the PROFIT, firm size have a negative effect, while FDR and BOPO have no effect on NPF.

\section{Conceptual Framework}

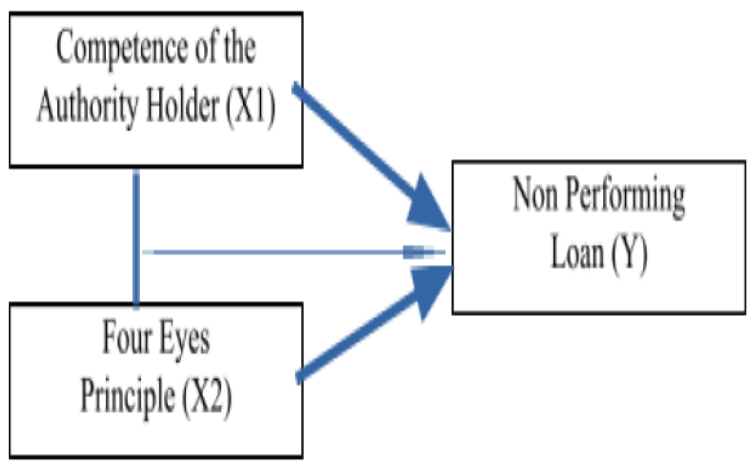

Figure 1. Conceptual Framework

\section{Hypothesis}

1. Competence of authority holders has a negative and significant effect on efforts to minimize non-performing loans. 
Edi Faisal Harahap et.al. The effect of the credit deciding authority competency and the effectiveness of applying the four eyes principle to minimize non performing loans on small medium enterprise segment in Pt. Bank Mandiri (Persero) Tbk Region I Sumatera I.

2. Application of the Effective Four Eyes Principle method has a negative and significant effect to minimize nonperforming loans

3. There is a negative and significant impact on competence and the simultaneous application of the Four Eyes Principle method to control nonperforming loans.

\section{RESEARCH METHOD}

This type of research is a descriptive study and this research will be conducted with quantitative and qualitative approaches to determine how the influence of the competence of authority holders and the application of the Four Eyes Principle method to minimize non-performing loans in the Small Medium Enterprise segment at PT. Bank Mandiri (Persero) Tbk Region I Sumatera I. The population in this study were all authority holders in the Small Medium Enterprise (SME) segment at Bank Mandiri (Persero) Tbk Region I Sumatera I, which includes authority holders in the Small Management Enterprise Business Unit and in Retail Risk unit. The number of population to be studied was 31 respondents. The research sample uses the entire population. Data collection techniques using questionnaires and interviews.

\section{RESULT AND DISCUSSION}

Table 1. Multiple Liner Regression Analysis

\begin{tabular}{|c|c|c|c|c|c|c|c|}
\hline \multirow[b]{2}{*}{ Model } & \multicolumn{2}{|c|}{$\begin{array}{l}\text { Unstandardized } \\
\text { Coefficients }\end{array}$} & \multirow{2}{*}{$\begin{array}{c}\begin{array}{c}\text { Standardiz } \\
\text { ed } \\
\text { Coefficient } \\
\text { s }\end{array} \\
\text { Beta }\end{array}$} & \multirow[b]{2}{*}{$\mathrm{t}$} & \multirow[b]{2}{*}{ Sig. } & \multicolumn{2}{|c|}{$\begin{array}{l}\text { Collinearity } \\
\text { Statistics }\end{array}$} \\
\hline & $\mathrm{B}$ & Std. Error & & & & $\begin{array}{c}\text { Toleranc } \\
\mathrm{e}\end{array}$ & VIF \\
\hline $1 \quad$ (Constant) & 6.773 & .499 & & 13.583 & .000 & & \\
\hline $\begin{array}{l}\text { Competence of the } \\
\text { Authority Holder } \\
\text { (X1) }\end{array}$ & $\begin{array}{l}-.344 \\
-.278\end{array}$ & .105 & -.444 & -2.996 & .006 & .797 & $\begin{array}{r}1.25 \\
5 \\
1.25 \\
5\end{array}$ \\
\hline
\end{tabular}

a. Dependent Variable: Kredit Bermasalah (Y) Sumber: Hasil Pengolahan Data

Obtained a multiple linear regression equation as follows:

$$
\mathrm{Y}=6.773-0.344 \mathrm{X} 1-0.278 \times 2+\mathrm{e}
$$

Based on this equation, it can be interpreted as follows:

1. The constant value is 6.773 . This value can be interpreted if the competence of the authority holder and the Four Eyes Principle is not there, then the value of the dependent variable on nonperforming loans is 6.773 .

2. The regression coefficient value of the competence of the authority holder is 0.344 . This value can be interpreted as when the competence of the authority holder increases, the non-performing loans will decrease. This means that the competency variable has a negative effect on efforts to minimize nonperforming loans in the Small Medium Enterprise (SME) segment.

3. The regression coefficient value of the Four Eyes Principle is -0.278 . This value can be interpreted that when the Four Eyes Principle goes up, non-performing loans go down. This means that the Four Eyes Principle variable has a negative influence on efforts to minimize nonperforming loans in the Small Medium Enterprise (SME) segment. 
Edi Faisal Harahap et.al. The effect of the credit deciding authority competency and the effectiveness of applying the four eyes principle to minimize non performing loans on small medium enterprise segment in Pt. Bank Mandiri (Persero) Tbk Region I Sumatera I.

Tabel 2. Simultaneous Significance Test (Test F)

\begin{tabular}{|l|r|r|r|r|r|}
\hline Model & Sum of Squares & df & Mean Square & F & Sig. \\
\hline 1 Regression & 5.855 & 2 & 2.927 & 14.490 & $.000^{2}$ \\
Residual & 5.657 & 28 & .202 & & \\
Total & 11.512 & 30 & & & \\
\hline \multicolumn{1}{|l|}{ a. Predictors: (Constant). Four Ey es Principle (X2), Kompetensi Pemegang Kewenangan (X1) } \\
\hline
\end{tabular}

b. Dependent Variable: Kredit Bermasalah (Y)

a. Predictors: (Constant), Four Eyes Principle (X2), Competence of Authority Holders (X1) b. Dependent variable : Non Performing Loan $(Y)$

Based on the above calculations, it can be seen that the calculated $F$ value is 14,490 with a p-value (sig) of 0,000 . With $\alpha$ $=0.05 \mathrm{df} 1=2$, and $\mathrm{df} 2=28$, then the $\mathrm{F}$ table is 3.34. Due to the value of $F_{\text {count }}>$ $F_{\text {table }}(14.490>3.34)$, it can be concluded simultaneously (simultaneously) that the competence of the authority holder and the implementation of the four Eyes Principle has a significant effect on efforts to minimize non-performing loans. Based on these results, if the holder of authority has good competence (motive, character, attitude, knowledge and skills) and good implementation of the Four Eyes Principle, then this will be able to minimize nonperforming loans.

Table 3. Analysis of the coefficient of determination

Model Summary ${ }^{\mathrm{b}}$

\begin{tabular}{|c|c|c|c|c|c|}
\hline Model & $\mathrm{R}$ & R Square & $\begin{array}{l}\text { Adjusted R } \\
\text { Square }\end{array}$ & $\begin{array}{l}\text { Std. Error of the } \\
\text { Estimate }\end{array}$ & Durbin-Watson \\
\hline 1 & $.713^{\mathrm{g}}$ & .509 & .474 & .44948 & 1.935 \\
\hline
\end{tabular}

The value of the coefficient of determination (R-Square) is 0.509. This value can be interpreted as the competency variable of the authority holder, the Four
Eyes Principle is able to influence nonperforming loans by $50.9 \%$, the remaining $100 \%-50.9 \%=49.1 \%$ explained by other variables or factors.

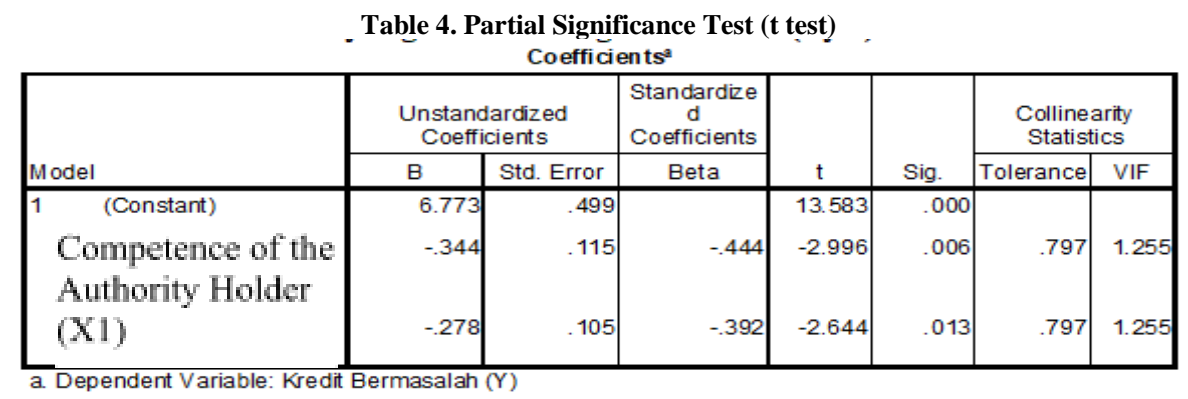

1. The coefficient value of the competence of the authority holder is -0.344 , which is negative. This means that the competence of the authorities has a negative effect on non-performing loans. It is known that the Sig value of the competent authority variable is 0.006 $<0.05$ and $\mathrm{t}$ count $|-2.996|>\mathrm{t}$ table | $2.04 \mid$, then the competence of the authority holders has a negative and significant effect on non-performing loans. This means that $\mathrm{HO}$ is rejected and $\mathrm{H} 1$ is accepted, so it can be concluded that the competence of the authority holders has an effect on efforts to minimize non-performing loans.

2. The coefficient value of the Four Eyes Principle is -0.278 , which is negative. This means that the Four Eyes Principle has a negative effect on non-performing 
Edi Faisal Harahap et.al. The effect of the credit deciding authority competency and the effectiveness of applying the four eyes principle to minimize non performing loans on small medium enterprise segment in Pt. Bank Mandiri (Persero) Tbk Region I Sumatera I.

loans. It is known that the Sig value of the four eyes principle variable is 0.013 $<0.05$ and t count $|-2.644|>\mathrm{t}$ table | $2.04 \mid$, then the Four Eyes Principle has a negative and significant effect on nonperforming loans. This means that $\mathrm{H} 0$ is rejected and $\mathrm{H} 1$ is accepted, so it can be concluded that the four eyes principle has an effect on efforts to minimize nonperforming loans.

The competence of the authority holder has an effect on efforts to minimize nonperforming loans.

Based on data obtained from distributing questionnaires conducted to 31 authority holders for the Small Medium Enterprise (SME) segment of PT. Bank Mandiri (Persero) in Region 1 Sumatera I obtained responses from respondents whose highest score for competency variables was in the dimension of character competency with an average score of $88.39 \%$ or in the $84 \%-100 \%$ (very high) category. This can be due to the nature / character is a core competency and the basis for other competencies (Spencer and Spencer in Harmein Nasution and Iskandarini Soetadi, 2012), so that in the iceberg model, traits (together with motives, self-concept, attitude, value system and self-image) is a difficult (invisible) competency and forms the basis for the development of other competencies. Traits are what make people behave or how someone responds to something in a certain way, so that the characteristics of a good authority holder will result in a good quality credit decision.

\section{The more effective the application of the Four Eyes Principle method will have an effect on efforts to minimize non- performing loans}

Based on the distribution of the questionnaire the indicator score is $84.16 \%$ (very high) on average, where the percentage is in the $84 \%-100 \%$ range. For the statement "the proposal decided with the credit committee is in accordance with the committee's authority" with a score of
$89.68 \%$ (very high). From the results of distributing questionnaires, it can be concluded that respondents believe that every decision made by the authority holder in the context of decision making using the Four Eyes Principle method has been and must be in accordance with the authority possessed by each authority holder. This orderliness needs to be maintained in order to make the Four Eyes Principle an appropriate decision-making strategy in the Small Medium Enterprise (SME) segment to maintain credit quality.

The competence of the authority holders and the implementation of the Four Eyes Principle strategy, both simultaneously and partially, were able to influence nonperforming loans at Bank Mandiri (Persero) Region I Sumatera I.

Based on the distribution of questionnaires to respondents in an effort to minimize non-performing loans, an average score of $82.76 \%$ was obtained, the value of this response was in the $68 \%-84 \%$ (high) category, with business prospects, debtor performance and ability to pay as indicators. Of the three indicators, respondents gave the highest response to the ability to pay for non-performing loans with a score of $87.76 \%$.

Furthermore, the indicator of the ability to pay the highest with a score of $91.51 \%$ is the question item "monitoring is early anticipation to obtain fast and accurate business information". From the response to the results of the distribution of the questionnaire, it can be concluded that monitoring of the debtor's account and business is an effective tool to anticipate any deviation or decline in the debtor's business which will have an impact on reducing credit collectability.

\section{CONCLUSION}

1. Partially, the competence of the authority holders has an effect on efforts to minimize non-performing loans, namely $34.4 \%$ and the remaining $63.6 \%$ is influenced by other variables. After 
Edi Faisal Harahap et.al. The effect of the credit deciding authority competency and the effectiveness of applying the four eyes principle to minimize non performing loans on small medium enterprise segment in Pt. Bank Mandiri (Persero) Tbk Region I Sumatera I.

testing the hypothesis, it is known that there is an effect of competence on efforts to minimize non-performing loans in the Small Medium Enterprise (SME) segment at PT. Bank Mandiri (Persero) Tbk Region I Sumatera I. Competence has a positive effect, which means that non-performing loans in the Small Medium Enterprise (SME) segment will decrease if the competence of the authority holders is good. The competencies that need to be the management's attention are traits and attitudes / attitudes, although motives, skills and knowledge are not the main indicators, considering that the Small Medium Enterprise (SME) segment is a credit business segment that has just been entered into aggressively by Mandiri. credit management staff and authority holders need to be continuously improved to ensure credit quality in the future.

2. Partially, the application of the Four Eyes Principle will affect efforts to minimize non-performing loans, namely $27.8 \%$ and the remaining $72.2 \%$ is influenced by other variables. After testing the hypothesis, it was found that there was a positive influence on the application of the Four Eyes Principle in making credit decisions, which means that the application of the Four Eyes Principle as a risk management strategy in credit management at PT. Bank Mandiri (Persero) Tbk Region I Sumatera I will guarantee the credit quality of the Small Medium Enterprise (SME) segment will be good.

3. Simultaneously and jointly with the competence of the authority holders and the application of the Four Eyes Principle as a method for making credit decisions, are able to influence nonperforming loans in Bank Mandiri (Persero) Region I Sumatera I by 50.9\% while the remaining $49.1 \%$ is influenced by variables other. After testing the hypothesis, it was found that there was an influence between the competence of the authority holder and the application of the Four Eyes Principle on nonperforming loans at Bank Mandiri (Persero) Tbk Regional I Sumatera I. Competence and implementation of the Four Eyes Principle had a positive effect, which means the better the competence of the authority and the implementation of the Four Eyes Principle will also improve the quality of credit for the Small Medium Enterprise (SME) segment.

\section{Acknowledgement: None}

\section{Conflict of Interest: None}

\section{Source of Funding: None}

\section{REFERENCES}

1. Tohir, Noel Chabannel. 2012. Panduan Lengkap Menjadi Acoount Officer. Jakarta: PT. Gramedia Pustaka.

2. Fahmi, Irham. 2011. Manajemen Risiko. Bandung: Alfabeta.

3. Kasmir, 2012. Manajemen Perbankan. Jakarta: Raja Grafindo Persada.

4. Karim, Adiwarman A. 2010. Bank Islam Analisis Fiqih dan Keuangan. Jakarta: Raja Grafindo Persada.

5. Ismail. 2010. Manajemen Perbankan dari Teori Menuju Aplikasi. Jakarta: Kencana

6. Bank Indonesia,2012, Peraturan Bank Indonesia nomor 14/15/PBI/2012 tentang Penilaian Kualitas Aset Bank Umum

7. Rivai, Veithzal dan Andria peramata Veitzhal.. Kredit manajemen hand book, (Jakarta :PT. raja Grafindo Persada,2013)

8. Indonesia, I. B. (2015). Manajemen Risiko 1 Mengidentifikasi Risiko Pasar, Operasional dan Kredit Bank. Jakarta: Gramedia Pustaka Utama.

9. Kasidi. 2014. Manajemen Risiko. Bogor: Penerbit Ghalia Indonesia.

10. Irham Wahyudi, "Strategi Mitigasi Risiko", www.apb-group.com/strategi-mitigasirisiko-1/ diakses pada tanggal 17 Oktober 2017.

11. Suwanda Dadang, Dailibas. 2013. Sistem Pengendalian Pemerintah. Jakarta Pusat: PPM 
Edi Faisal Harahap et.al. The effect of the credit deciding authority competency and the effectiveness of applying the four eyes principle to minimize non performing loans on small medium enterprise segment in Pt. Bank Mandiri (Persero) Tbk Region I Sumatera I.

12. Yap, Pardjo, 2017, Panduan Praktis Manajemen Risiko Perusahaan: rowing Publishing.

13. Sharifi,S, Haldar,A, Rao Nageswara, SVD, (2018),'The relationship between credit risk Management and non-performing assets of Commercial banks in India", anagerial Finance juornal, vol 45 no.3, pp 399-412.

14. Nurwahjuni, Shomad, Abd, (2016),'For eyes Principle dalam pengelolaan risiko kredit pada bank, Yuridika jurnal,vol 31 no. 2

15. Sasongko, Hajar. (2008). Analisis FaktorFaktor Yang Mempengaruhi Kompetensi Tenaga Penjualan Untuk Meningkatkan Kinerja Tenaga Penjualan. Thesis, Program Studi Magister Manajemen Program Pasca Sarjana Universitas Diponegoro Semarang.

16. Rusdianti Endang, Wardoyo Paulus, Setyarini Ani, (2018),'Peran Account Officer dalam menekan kredit bermasalah, Dinamika Sosial Budaya Jurnal, vol 20, No. 2, pp 182-192.

17. Sharif Adnan, Irwanto Kohar Abdul, Maulana Ahmad Nur Tubagus,(2015)," Strategi optimasi Sistem Manajemen Resiko Pembiayaan pada Bank Jabar Banten Syariah, Manajemen IKM Jurnal, Vo.10, no. 2, pp 143-150.

18. Hanafi M Mamduh (2014), Risiko, Proses Manajemen Resiko dan Enterprise Risk
Management", www.Slideshare.net/EKMA4262/Modul I accessed 05 April 2020.

19. Harmein Nasution, Iskandarini Soetadi (2012),"Proses pengelolaan SDM berdasarkan kompetensi", USU Press

20. Sinulingga Sinuraya (2018), " Metode Penelitian", USU Press.

21. Arikunto Suharsimi (2013)," Prosedur Penelitian suatu pendekatan praktik", Jakarta : PT. Rineka Cipta

22. Martin Brown, (et,al),'The Hidden Costs of Control-Evidence from Small Business Lending'(2004) http://www.nccrfinrisk.uzh.ch/media/pdf/SFIResearchDay20 13_Brown_paper2.pdf $>$ accessed 26 Desember 2020

23. Sugiyono (2016)," Metode Penelitian Kuantitatif Kualitatif dan R\&D”, Bandung. CV Alfabeta,

How to cite this article: Harahap EF, Nasution $\mathrm{H}$, Absah $\mathrm{Y}$. The effect of the credit deciding authority competency and the effectiveness of applying the four eyes principle to minimize non performing loans on small medium enterprise segment in Pt. Bank Mandiri (Persero) Tbk Region I Sumatera I. International Journal of Research and Review. 2021; 8(4): 79-85. DOI: https://doi.org/10.52403/ijrr.20210412 